2. Van Haren RM, Mehran RJ, Mena GE, Correa AM, Antonoff MB, Baker CM, et al. Enhanced recovery decreases pulmonary and cardiac complications after thoracotomy for lung cancer. Ann Thorac Surg. 2018;106:272-9.

3. Haro GJ, Sheu B, Marcus SG, Sarin A, Campbell L, Jablons DM, et al. Perioperative lung resection outcomes after implementation of a multidisciplinary, evidence-based thoracic ERAS program. Ann Surg. December 5, 2019 [Epub ahead of print].
4. Nelson DB, Mehran RJ, Mitchell KG, Correa AM, Sepesi B, Antonoff MB, et al Enhanced recovery after thoracic surgery is associated with improved adjuvant chemotherapy completion for non-small cell lung cancer. J Thorac Cardiovasc Surg. 2019;158:279-86.e1.

5. Antonoff MB. Commentary: predicting patients at risk for complications after thoracic surgery-application in the era of enhanced recovery. J Thorac Cardiovasc Surg. 2019;157:2502-3.
See Article page 1689.

\section{Commentary: Enhanced recovery and postoperative opioid use: Good for the patient, good for society?}

\author{
Timothy J. P. Batchelor, BSc, MBChB, MSc, FRCS \\ (CTh)
}

Some elements of patient care, including opioid use for acute pain management, are associated with delayed recovery from surgery. ${ }^{1}$ Furthermore, prescription opioids are implicated in the so-called opioid epidemic experienced most keenly in North America ${ }^{2}$ but now also seen increasingly elsewhere. ${ }^{3}$ Although the causes of the opioid crisis are complex, changes in perioperative prescribing practices with newer formulations of synthetic opioid analgesics are partly to blame. Approximately 5\% of patients prescribed opioids will go on to become dependent on them. ${ }^{4}$

Enhanced recovery after surgery (ERAS) describes a multifaceted approach to perioperative care that aims to reduce the body's deleterious stress response to surgery and thus accelerate recovery. A key component is an opioid-sparing approach to pain relief. Recommendations after lung cancer surgery include patient education, regional anesthesia (preferably without thoracic epidural), acetaminophen in combination with nonsteroidal antiinflammatory drugs, glucocorticoids, and ketamine. ${ }^{5}$ Other potential adjuncts, such as liposomal bupivacaine and the

\footnotetext{
From the Department of Thoracic Surgery, University Hospitals Bristol NHS Foundation Trust, Bristol Royal Infirmary, Bristol, United Kingdom.

Disclosures: Dr Batchelor reports honoraria from Medtronic and Johnson \& Johnson, and consultancy fees from AstraZeneca.

Received for publication Jan 12, 2020; accepted for publication Jan 14, 2020; available ahead of print Jan 25, 2020.

Address for reprints: Timothy J. P. Batchelor, BSc, MBChB, MSc, FRCS (CTh), Department of Thoracic Surgery, University Hospitals Bristol NHS Foundation Trust, Bristol Royal Infirmary, Bristol BS2 8HW, United Kingdom (E-mail: tim. batchelor@uhbristol.nhs.uk).

J Thorac Cardiovasc Surg 2021;161:1703-4

$0022-5223 / \$ 36.00$

Copyright (C) 2020 by The American Association for Thoracic Surgery

https://doi.org/10.1016/j.jtcvs.2020.01.020
}

\section{Check for updates}

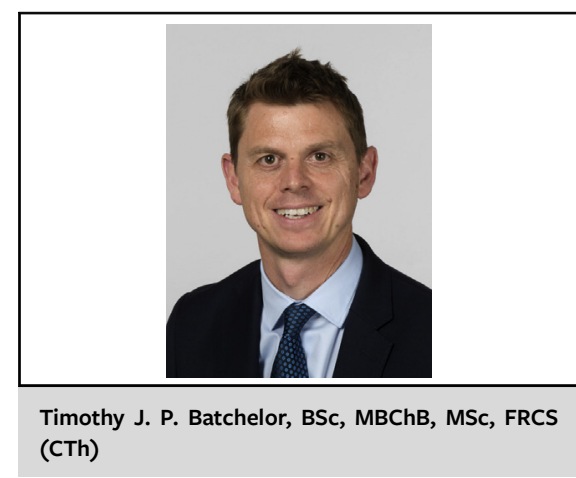

CENTRAL MESSAGE

Enhanced recovery programs

reduce opioid consumption

postoperatively and after

discharge with potential benefi-

cial effects for both the individual

patient and the opioid epidemic.

prophylactic use of gabapentinoids, show promise and are subject to ongoing studies.

In this issue of the Journal, Razi and colleagues ${ }^{6}$ describe the successful implementation of an ERAS program after thoracic surgery. Their goal was to unify patient care by consolidating perioperative care elements into one ERAS protocol, thereby streamlining the patient pathway and reducing variability in outcomes. They achieved reductions in in-hospital postoperative pain scores for both open and robotic lung resections. At the same time, they observed a reduction in in-hospital opioid use for robotic surgery but not open surgery (although this may be due to the laudable elimination of thoracic epidurals in the open group). Perhaps the most important outcome, however, was the striking reduction in postdischarge opioid use, most marked in the open group of patients. This information was available to the authors because Florida has a statewide 
database that captures all opioid prescriptions as part of a drug-monitoring program.

In addition to their potential contribution to the opioid crisis, there are other properties of prescription opioids that can cause harm. In the short term, side effects (nausea, constipation, sedation, depressed ventilation, and suppression of coughing) may affect a patient's ability to achieve ERAS targets such as nausea and vomiting control, early mobilization, and a quick return to an oral diet. In the longer-term, there may be effects on cancer survival. Opioid receptors are overexpressed in lung cancer cells, and stimulation promotes proliferation and migration. ${ }^{7}$ Whether this translates into poorer clinical outcomes is not known because study results are mixed, but among the noise there is a suggestion that opioids may promote metastasis and reduce survival given the right conditions. ${ }^{8}$

ERAS pathways eliminate variations in practice and allow all patients to receive optimal, person-independent perioperative care. There are known associated beneficial outcomes, such as a reduction in complications, a shorter length of stay, and lower hospital costs. It is possible that, through opioid avoidance, there are longer-term consequences that will benefit both the individual patient with lung cancer and society at large.

\section{References}

1. Ljungqvist $\mathrm{O}$, Scott M, Fearon KC. Enhanced recovery after surgery: a review. JAMA Surg. 2017;152:292-8.

2. Sharfstein JM, Olsen Y. Lessons learned from the opioid epidemic. JAMA. 2019; 322:809-10.

3. Smith BH, Fletcher EH, Colvin LA. Opioid prescribing is rising in many countries. BMJ. 2019;367:15823.

4. Higgins C, Smith BH, Matthews K. Incidence of iatrogenic opioid dependence or abuse in patients with pain who were exposed to opioid analgesic therapy: a systematic review and meta-analysis. Br J Anaesth. 2018; 120:1335-44.

5. Batchelor TJP, Rasburn NJ, Abdelnour-Berchtold E, Brunelli A, Cerfolio RJ, Gonzalez M, et al. Guidelines for enhanced recovery after lung surgery: recommendations of the Enhanced Recovery After Surgery (ERAS $®$ ) Society and the European Society of Thoracic Surgeons (ESTS). Eur J Cardiothorac Surg. 2019;55:91-115.

6. Razi SS, Stephens-McDonnough JA, Haq S, Fabbro M II, Sanchez AN, Epstein RH, et al. Significant reduction of postoperative pain and opioid analgesics requirement with an enhanced recovery after thoracic surgery protocol. J Thorac Cardiovasc Surg. 2021;161:1689-701.

7. Lennon FE, Mirzapoiazova T, Mambetsariev B, Salgia R, Moss J, Singleton PA. Overexpression of the $\mu$-opioid receptor in human non-small cell lung cancer promotes Akt and mTOR activation, tumor growth, and metastasis. Anesthesiology. 2012;116:857-67.

8. Wall T, Sherwin A, Ma D, Buggy DJ. Influence of perioperative anaesthetic and analgesic interventions on oncological outcomes: a narrative review. Br J Anaesth. 2019;123:135-50. 